\title{
CHEMOSPHERE
}

\section{Resistance to metal contamination by historically-stressed populations of Ceriodaphnia pulchella: Environmental influence versus genetic determination}

\author{
Isabel Lopes ${ }^{\text {a }}$, Donald J. Baird ${ }^{\mathrm{b}}$, Rui Ribeiro ${ }^{\mathrm{a}, *}$ \\ a Instituto do Ambiente e Vida, Departamento de Zoologia da Universidade de Coimbra, Largo Marquês de Pombal, \\ 3004-517 Coimbra, Portugal \\ ${ }^{\mathrm{b}}$ Department of Biology, NWRI (Environment Canada), Canadian Rivers Institute, University of New Brunswick, \\ 10 Bailey Drive, P.O. Box 45111, Fredericton, New Brunswick, Canada E3B 6 E1
}

Received 8 June 2004; received in revised form 25 January 2005; accepted 22 February 2005

Available online 19 April 2005

\begin{abstract}
Field populations of daphnids historically-stressed by metal contamination may show increased resistance to those contaminants. This study was undertaken aiming to confirm/infirm three main hypotheses: (1) field populations living in historically-impacted environments are more tolerant to metal stress than populations from reference sites; (2) resistance differences are genetically-determined, i.e., differences persist after controlling for environmental and maternal effects, by acclimating cloned lineages to similar conditions; and (3) resistance to stress in field populations living in historically-impacted environments is due to the disappearance of sensitive individuals rather than the appearance of highly resistant ones, i.e., the shift in the central tendency of resistance is linked to a decrease in the range of population resistance and not to an increased upper limit of the population resistance. Three populations of the cladoceran Ceriodaphnia pulchella Sars in Southern Portugal were sampled; one of which has been historically-stressed by acid mine drainage (AMD) from an abandoned cupric-pyrite mine and two from reference sites within the same watershed. To assess if resistance differences were genetically-determined, the three populations were acclimated for at least five generations under the same controlled conditions. Assays with AMD contaminated water samples were performed with both non-acclimated and acclimated individuals from all studied populations. Reproduction results in sub-lethal assays revealed significant differences between the reference and stressed populations. Significant differences in resistance to lethal levels of toxicity were observed for both non-acclimated and acclimated populations, individuals from population I being more resistant than those from reference populations. The existence of genetically-determined sensitivity differences was attested by the presence of significant differences in resistance to lethal levels of toxicity in acclimated individuals from reference and stressed populations. Results from cumulative mortality assays revealed that sensitive individuals were most probably present in the original population, but no conclusion could be draw about the presence of extreme resistant individuals in the historically-stressed population. Finally, it was shown that responses among populations converged from high to low levels of contamination.
\end{abstract}

(c) 2005 Elsevier Ltd. All rights reserved.

\footnotetext{
${ }^{*}$ Corresponding author. Tel.: +351 239 822241; fax: +351 239826798 .

E-mail address: rui.ribeiro@zoo.uc.pt (R. Ribeiro).
} 
Keywords: Sensitivity; Adaptation; Metals; Acid mine drainage; Ceriodaphnia pulchella

\section{Introduction}

The toxicity of heavy metals to aquatic organisms is well documented in terms of both lethal (Mance, 1987; Wiederholm and Dave, 1989; Gerhardt, 1995; Jak et al., 1996; Villaescusa et al., 1997) and sub-lethal effects (Mance, 1987; Hickey, 1989; Gerhardt, 1995; Miliou et al., 1998). Heavy metals can stress organisms by different mechanisms affecting the cell membrane (e.g., ion transport mechanisms), the DNA (e.g., inhibiting the transcription process), by causing oxidative damage (Stohs and Bagchi, 1995), and by causing damage to the nervous system and to the function of enzymes (Depledge et al., 1994; Gerhardt, 1995). Several metal detoxification mechanisms are found in individuals, for example, the production of metallothioneins, which captures and retain metal ions (Hamer, 1986; Roesijadi, 1992) and the accumulation and retention (e.g., by mineralisation) of heavy metals in specific regions and organs (Borgmann et al., 1993; Cope et al., 1994; Lucan-Bouché et al., 1999; Munger et al., 1999). The diversity in these physiological responses allows a population living in an impacted environment, i.e., under a strong selection pressure, to acquire resistance to metals (Brown, 1978; Klerks and Weis, 1987; Bodar et al., 1990; Posthuma et al., 1992; Stuhlbacher and Maltby, 1992; Donker et al., 1993; Shirley and Sibly, 1999). Tolerance to heavy metals can be acquired either by environmentally-induced physiological alterations, including those due to stress-induced gene expression (Stuhlbacher and Maltby, 1992; Stuhlbacher et al., 1993; Maltby and Crane, 1994; Lam, 1996, 1999) or by quantitative and/or qualitative changes in gene frequencies (Klerks and Weis, 1987; Gill et al., 1989; Posthuma et al., 1992; Lam, 1999). Some complications may arise when trying to differentiate these hypotheses. For example, techniques that control for environmental influence involve screening tolerance after acclimation to controlled conditions (Maltby et al., 1987; Lam, 1999). One of the major problems is to which extent maternal influence persist in the F1, F2 and, even later generations. This problem can be diminished by culturing animals under laboratory conditions and screen tolerance to stress in F1 or later generation progeny.

The acquisition of resistance to toxicants may lead to a decrease in the genetic diversity of the population (Van Straaalen and Timmermans, 2002). Actually, there is some support for the genetic erosion hypothesis, more specifically at the molecular basis. Krane et al. (1999) analysed RAP DNA polymerase chain reaction-generated DNA from eight different population of Orconectes rusticus and found that changes in genetic diversity was significantly correlated with the extent to which the population had been exposed to contaminants. Also, Murdoch and Hebert (1994) observed that diversity of mitochondrial DNA of brown bullhead fish was lower in populations from contaminated rivers relatively to populations from relative pristine sites.

To study the resistance of field populations under exposure to long-term metal stress, three field populations of the lake-dwelling cladocerans Ceriodaphnia pulchella Sars were selected to carry out this study. Daphnids are particularly suitable to investigate genetically-determined resistance to contamination since they exhibit facultative asexual reproduction by ameiotic parthenogenesis. Furthermore, data acquisition on cladocerans' resistance is particularly relevant since these individuals are widely used, as standard test species (particularly, Daphnia magna and Ceriodaphnia dubia) in hazard assessment studies. Surprisingly, scarce information related to resistance acquisition by field population of Cladocera is available from published literature (revision made by Reznick and Ghalambor, 2001).

In this study, two experimental approaches were undertaken aiming to test three questions: (1) are field populations living in historically-impacted environments more tolerant to metal stress than populations from reference sites? (Experiment 1); (2) are these differences genetically-determined, i.e., do differences persist after controlling environmental and maternal effects, by acclimating individual lineages to similar conditions for several generations? (Experiment 2); (3) is the resistance to metal stress observed in field populations living in historically-impacted habitats due to the disappearance of sensitive individuals or to the appearance of highly resistant individuals, i.e., is the shift in the central tendency of resistance linked to a decrease in the population resistance range of responses rather than to an increased upper limit of the population resistance? (Experiment 2). To investigate metal resistance in this species, field populations were sampled in a well studied, isolated aquatic system impacted by acid mine drainage (AMD), where other industrial, agricultural or urban runoff sources are absent.

\section{Materials and methods}

\subsection{Study site}

An aquatic system impacted with AMD, from an abandoned cupric-pyrite mine (active from 1859 to 


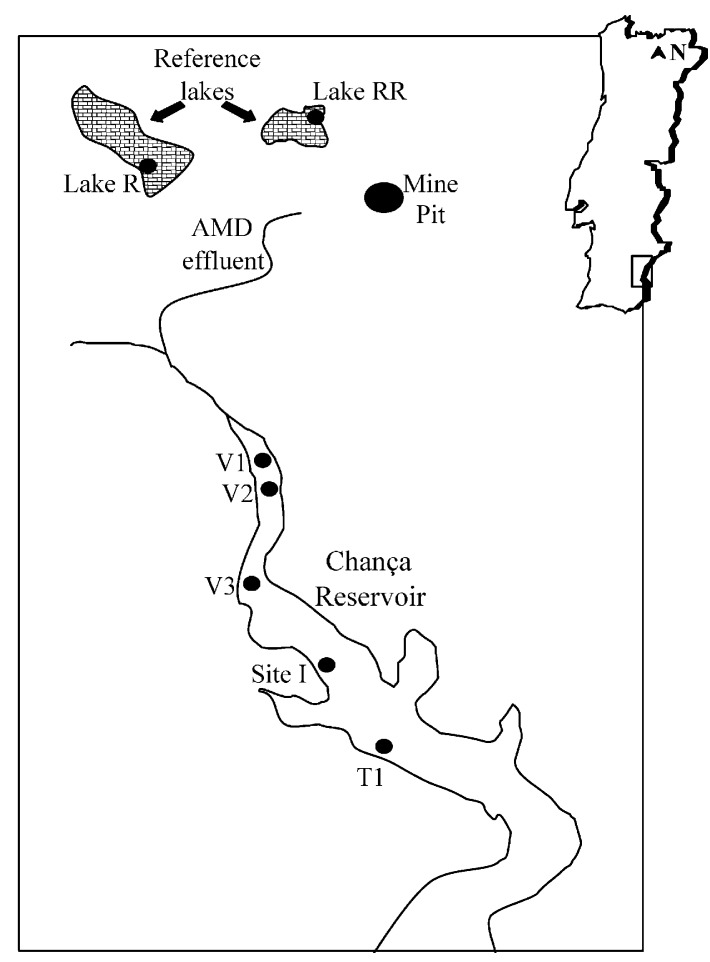

Fig. 1. Map of the aquatic system of Chança Reservoir (SE Portugal) where populations of Ceriodaphnia pulchella were sampled (lakes R and RR, and site I), and where water samples (V1 to V3 and T1) were collected.

1966), was selected for the development of this study (Fig. 1). The oxidation of the pyrite environment produces an effluent with high concentrations of heavy metals and very low pH (Kelly, 1988; Sengupta, 1993). The ongoing oxidation of abandoned mine tailings continuously leads to the production of a very acid effluent, highly contaminated with heavy metals $(\mathrm{Fe}, \mathrm{Al}, \mathrm{Zn}$, $\mathrm{Cu}, \mathrm{Mn}, \mathrm{Co}, \mathrm{Ni}, \mathrm{Cd}, \mathrm{Pb}, \mathrm{Cr}$, As; in decreasing order, Lopes et al., 1999a; Pereira et al., 2000) (Table 1), which is discharged without a treatment into the Chança Reservoir located in the Guadiana River Basin (SE Portugal). The $\mathrm{pH}$ of this reservoir is close to neutrality since the low $\mathrm{pH}$ of the effluent is neutralised by dilution. For the water samples used in bioassays (V1-V3 and T1), data on 12 metals, measured by atomic absorbance spectroscopy, from previously collected samples with almost matching conductivity values are presented in Table 1. Further metal analyses were considered unnecessary since no concentration-effect relationships were intended to be established, but solely the comparison of relative sensitivities between populations.

This aquatic system is highly suited for the study of adaptations occurring in natural populations exposed to historical chemical stress, for three reasons: (i) the source of contamination is isolated and identified $(\mathrm{pH}$
Table 1

Alkalinity ( $\left.\mathrm{mg} \mathrm{CaCO}_{3} / \mathrm{l}\right)$ and concentrations (mg/l) of metals (total recoverable) from previously collected water samples, with close conductivity values $(\mu \mathrm{S} / \mathrm{cm})$ of those water samples used in this study

\begin{tabular}{lcc}
\hline & $\mathrm{V} 1-\mathrm{V} 3$ & $\mathrm{~T} 1$ \\
\hline Conductivity & $332-280$ & 202 \\
Previous conductivity & 312 & 271 \\
Previous alkalinity & 6.5 & 27.0 \\
$\mathrm{Al}$ & 11.3 & $<0.1$ \\
$\mathrm{As}$ & $<0.005$ & $<0.005$ \\
$\mathrm{Cd}$ & 0.0286 & 0.00082 \\
$\mathrm{Cr}$ & $<0.015$ & $<0.015$ \\
$\mathrm{Cu}$ & 1.7 & 0.027 \\
$\mathrm{Fe}$ & 1.64 & 0.129 \\
$\mathrm{Mn}$ & 3.07 & 0.081 \\
$\mathrm{Ni}$ & 68.0 & $<0.03$ \\
$\mathrm{~Pb}$ & 4.60 & 0.640 \\
$\mathrm{Hg}$ & $<0.0002$ & $<0.0002$ \\
$\mathrm{Co}$ & 90.0 & $<0.03$ \\
$\mathrm{Zn}$ & 12.10 & 0.288 \\
\hline
\end{tabular}

and, mainly, heavy metals); no agriculture or industrial activities are present and there is no urban runoff; (ii) reference sites free of metal mining contamination exist close to the contaminated area; (iii) extensive data on the biology, ecology and water chemistry of the system are available (Pereira et al., 1995; Ribeiro et al., 1995; Lopes et al., 1999a,b; Pereira et al., 1999, 2000; Castro et al., 2003, 2004; Moreira-Santos et al., 2004a,b).

\subsection{Assay organisms and culture conditions}

Two reference populations ( $\mathrm{R}$ and $\mathrm{RR}$ ) and one historically-stressed (I) population of Ceriodaphnia pulchella Sars were collected from two lakes $(\mathrm{R}-\mathrm{pH} 7.5$, $189 \mu \mathrm{S} / \mathrm{cm}, \mathrm{DO} 8.7 \mathrm{mg} / \mathrm{l}$; and $\mathrm{RR}-\mathrm{pH} 7.61,193 \mu \mathrm{S} /$ $\mathrm{cm}$, DO $9.3 \mathrm{mg} / \mathrm{l}$ ) located upstream the contaminated area, and one site located near the confluence of the AMD effluent with the Chança Reservoir ( $-\mathrm{pH}$ 7.0, $231 \mu \mathrm{S} / \mathrm{cm}$, DO $9.4 \mathrm{mg} / \mathrm{l}$ ), respectively (Fig. 1).

The procedure to sample field populations was as described by Lopes et al. (1999a). Individuals were brought to the laboratory, and, using a dissection microscope, 15 egg-bearing females from each population were transferred to culture beakers filled with $50-\mu \mathrm{m}$ filtered site water. Randomly sampled juveniles born the next day from those field-collected females were kept in $50-\mu \mathrm{m}$ filtered site water until used to perform toxicity assays, the remaining juveniles were reared in the laboratory and acclimated to controlled conditions (for at least five generations), which were as follows: $25 \pm 1{ }^{\circ} \mathrm{C}$ with a 14:10 h L:D cycle in American Society for Testing and Materials (ASTM) hardwater (ASTM, 2002), with added vitamins and the organic additive Marinure 25 (Baird et al., 1989); animals were fed daily with the green 
algae Pseudokirchneriella subcapitata (Koršhikov) Hindak (formerly known as Selenastrum capricornutum Printz) $\left(3 \times 10^{5}\right.$ cells $\left./ \mathrm{ml} / \mathrm{d}\right)$.

\subsection{Toxicity assays}

Lethal and sub-lethal toxicity assays were performed with neonates from the three $C$. pulchella populations under controlled conditions of temperature $\left(25 \pm 1^{\circ} \mathrm{C}\right)$ and photoperiod (14:10 h L:D cycle). Assays were conducted with laboratory-acclimated neonates (6-24-h old), from the third and fourth broods, and with non-acclimated neonates (6-24-h old) from recently field-collected egg-bearing females (USEPA, 1991). In lethal assays no food was added, while in sub-lethal assays individuals were fed daily with $P$. subcapitata $\left(3 \times 10^{5} \mathrm{cells} / \mathrm{ml} / \mathrm{day}\right.$, which corresponds to $1.2 \times 10^{7}$ cells/individual), with water being renewed every other day.

Conductivity (WTW, LF92, Weilheim, Germany), $\mathrm{pH}$ (WTW, 537) and dissolved oxygen (DO) (WTW, OXI 92) were monitored at each sampling site and at the beginning and at the end of each assay.

Two experiments were carried out:

\subsubsection{Experiment 1 -Sensitivity of reference versus stressed populations}

This experiment investigated differences in sensitivity to AMD contamination between the reference and the historically-stressed populations. Lethal (survival time - death within minutes to hours) and sub-lethal (reproduction) toxicity assays were carried out with non-acclimated neonates exposed to two Very Toxic (samples V1 and V2) and to one Moderately Toxic waters (sample T1). In survival time assays (neonates from the populations $\mathrm{R}$ and I were exposed to water samples V1 and V2), five individuals were introduced, one by one, in $42-\mathrm{ml}$ glass vessels filled with $15 \mathrm{ml}$ of water sample, with four replicates per treatment (20 individuals/treatment). Immobilisation (no movement after gentle prodding) was checked every $3 \mathrm{~min}$ from 15 to $30 \mathrm{~min}$, every $5 \mathrm{~min}$ from 30 to $120 \mathrm{~min}$, every $15 \mathrm{~min}$ from 2 to $6 \mathrm{~h}$, every hour from 6 to $12 \mathrm{~h}$ (Lopes et al., 1999b, 2000; Ribeiro et al., 2000). In reproduction assays (neonates from the populations R, RR and I were exposed to the water sample $\mathrm{T} 1$ ), each individual was introduced into $42-\mathrm{ml}$ glass vessels filled with $40 \mathrm{ml}$ of water sample, with 12 replicates per treatment. Reproduction was assessed daily by counting released neonates. Reproduction assays ended when all daphnids released the fourth brood.

\subsubsection{Experiment 2-Environmental versus genetic components of resistance}

This experiment investigated if differences in resistance to AMD contamination between reference and historically-stressed populations were due to environmental-induced physiological alterations or to local adaptation, and/or if those differences were due to the disappearance of most sensitive genotypes. Lethal (cumulative mortality - death within hours to dayswith the Very Toxic water V3) assays were conducted with acclimated neonates from the three populations. In cumulative mortality assays, five individuals were introduced simultaneously in $42-\mathrm{ml}$ glass vessels filled with $30 \mathrm{ml}$ of water sample, with four replicates per treatment. Immobilisation was checked every $24 \mathrm{~h}$. An assay ended when all the daphnids died or after $240 \mathrm{~h}$ of exposure if at least one individual survived that long.

\subsection{Data analysis}

Survival time and reproduction data were analysed with ANOVAs followed by post-hoc comparisons with the Tukey HSD test, and with $t$-tests when comparing only two samples (Zar, 1996). Survivorship curves with censored data from cumulative mortality assays were compared with the Gehan-Wilcoxon $\chi^{2}$-test (Pyke and Thompson, 1986). All these statistics, were performed using the program Statistica for Windows 4.3 (StatSoft, Aurora, CO, USA). The ET50 (median lethal time), with the respective $95 \% \mathrm{CI}$ and slopes, was computed using PriProbit 1.63 (Sakuma, 1998; http://bru.gmprc.ksu. edu/proj/priprobit/download.asp).

\section{Results}

Conductivity, $\mathrm{pH}$ and $\mathrm{DO}$ of water samples at the time of collection are presented in Table 2. No significant variations were observed in these parameters either between collection of the water and its use in the assays. Differences never exceeded $0.1 \mathrm{pH}$ units, $3 \mu \mathrm{S} / \mathrm{cm}$ conductivity or $0.2 \mathrm{mg} / 1 \mathrm{DO}$ in any experiment.

\subsection{Experiment 1 -Sensitivity of reference versus stressed populations}

In the first experiment, non-acclimated neonates, from recently field-collected egg-bearing females, were exposed to two Very Toxic (V1 and V2) and one Moderately Toxic (T1) water samples, aiming to detect

Table 2

Values of $\mathrm{pH}$, conductivity (Cond., $\mu \mathrm{S} / \mathrm{cm}$ ), and dissolved oxygen $(\mathrm{DO}, \mathrm{mg} / \mathrm{l})$ measured in the water samples used in toxicity assays

\begin{tabular}{lcccc}
\hline & $\mathrm{V} 1$ & $\mathrm{~V} 2$ & $\mathrm{~V} 3$ & $\mathrm{~T} 1$ \\
\hline $\mathrm{pH}$ & 3.5 & 3.8 & 6.0 & 7.5 \\
Cond. & 332 & 293 & 280 & 202 \\
DO & 9.7 & 8.6 & 9.4 & 10.2 \\
\hline
\end{tabular}




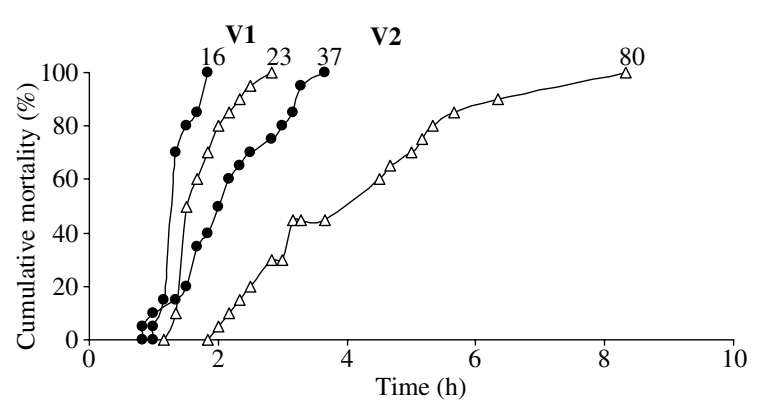

Fig. 2. Cumulative mortality assay with non-acclimated Ceriodaphnia pulchella neonates from the reference (closed circles) and the historically-stressed (open triangles) populations exposed to the water samples V1 and V2. Coefficients of variation $(\%)$ are presented.

differences, at lethal and sub-lethal levels, in sensitivity between the reference and the historically-stressed local populations. Lethal assays revealed that the population I was significantly more resistant to AMD contamination than the population $\mathrm{R}$, when exposed to water samples V1 and V2 ( $t$-tests: $t_{38}=3.48, p<0.001$ and $t_{38}=4.67, p<10^{-5}$, respectively for $\mathrm{V} 1$ and $\mathrm{V} 2$ ) (Fig. 2). The ET50s (CI) for population I and R were $1.62 \mathrm{~h}(1.50-1.72)$ and 3.71 (3.42-4.02), when exposed to water sample V1, and, $1.31 \mathrm{~h}(1.24-1.38)$ and $1.97 \mathrm{~h}$ (1.83-2.12), when exposed to V2. The slope of the survival curves was smaller in population I than in population $\mathrm{R}$, both when exposed to $\mathrm{V} 1$ or $\mathrm{V} 2$ water samples $(b=9.2,5.29 ; b=13.6,5.38$, respectively).

When exposed to the water sample V1, individuals from population $\mathrm{R}$ started to die $0.30 \mathrm{~h}$ earlier than those from the population I. During this 0.30 -h period population R presented already $15 \%$ mortality (Fig. 2). Furthermore, $30 \%$ of population I was still alive when the last individual from the population $\mathrm{R}$ died, and it took $1.10 \mathrm{~h}$ for those $30 \%$ to perish (Fig. 2). Similar results were obtained with the sample V2: $40 \%$ of population $\mathrm{R}$ died before any mortality in population I being observed, which started to occur only $1.17 \mathrm{~h}$ later (Fig. 2). Furthermore, by the time $100 \%$ of mortality was observed in population R, population I still presented $55 \%$ of survivals and it resisted for an extra 4.60-h period (Fig. 2).

When exposed to the water sample T1, individuals from the population I presented a significantly higher reproductive output than populations $\mathrm{R}$ and $\mathrm{RR}$ (1-way ANOVA: $F_{2,33}=4.68, p=0.016$ ) (Fig. 3).

\subsection{Experiment 2-Environmental versus genetic components of resistance}

In the second experiment, all three populations $(\mathrm{R}$, $R R$, and I) were fully acclimated to controlled conditions and exposed to the water sample V3. This phase in-

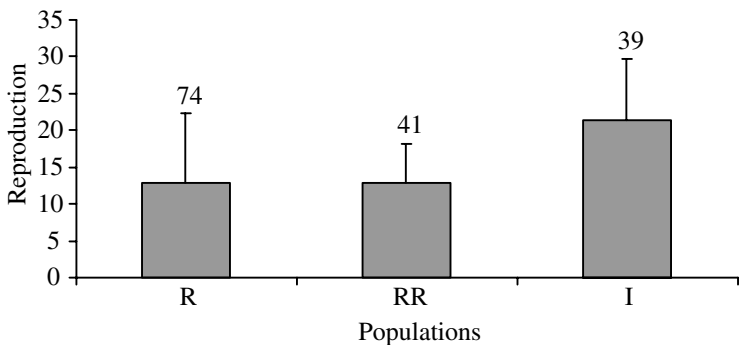

Fig. 3. Reproduction assay (neonates/female) (average + SD) with non-acclimated Ceriodaphnia pulchella neonates from reference (R and RR) and historically-stressed (I) populations exposed to the water sample T1. Coefficients of variation $(\%)$ are presented.

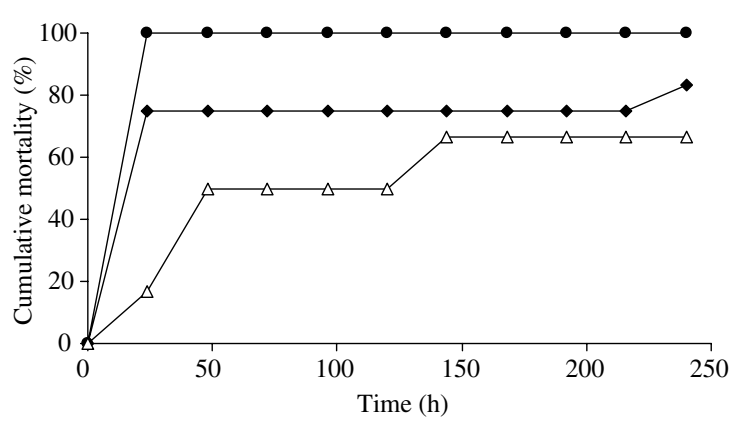

Fig. 4. Cumulative mortality assays with acclimated Ceriodaphnia pulchella neonates from reference populations $\mathrm{R}$ (closed circles) and RR (closed diamonds) and from the historically-stressed population I (open triangles) exposed to the water sample V3.

tended to assess if differences in sensitivity between populations were due to environmental-induced physiological alterations or to local adaptation.

Individuals from the reference populations exposed to water sample V3 showed significantly reduced survival over those from the historically-stressed population (Gehan-Wilcoxon test: $\chi_{2}^{2}=5.90, p=0.05$ ) (Fig. 4). After $240 \mathrm{~h}$ of exposure mortalities of $100 \%$, $83 \%$ and $67 \%$ were registered for the populations $\mathrm{R}$, $\mathrm{RR}$ and I, respectively. Furthermore, after $24 \mathrm{~h}$ of exposure only $17 \%$ of mortality was observed in the population I, while $100 \%$ and $75 \%$ were already attained by the populations R and RR, respectively (Fig. 4).

\section{Discussion}

\subsection{Sensitivity of reference versus stressed populations}

The first question asked in this study was if there were differences in sensitivity to AMD between reference and historically-stressed populations. The results 
obtained in the first experiment, by exposing non-acclimated individuals to two Very Toxic (V1 and V2) and one Moderately Toxic (T1) water samples, showed that individuals from population I presented a higher tolerance than those from uncontaminated site populations, both at lethal and sub-lethal levels of contamination (Figs. 2 and 3). These results were expected, since similar tolerance to metals has been reported in literature for a wide range of organisms; bacteria (Bruins et al., 2000), protists (Devars et al., 1998), plants (Macnair, 1997; Monni et al., 2000), and animals (Klerks and Weis, 1987; Posthuma and van Straalen, 1993). Furthermore, several authors have shown that tolerance to heavy metals can be induced in laboratory after a short pre-exposure period to metals (Bodar et al., 1990; Münzinger, 1990; Stuhlbacher and Maltby, 1992; Stuhlbacher et al., 1993). Reinecke et al. (1999) pre-exposed the terrestrial oligochaete Eisenia fetida for more than ten generations to sub-lethal concentrations of cadmium sulphate, and found that pre-exposed individuals were more tolerant to high cadmium concentrations than unexposed ones. This higher tolerance, acquired by the pre-exposed individuals, was due to environmentinduced physiological alterations (e.g., through the increased synthesis of binding proteins).

Results from the cumulative mortality assays with populations $\mathrm{R}$ and $\mathrm{I}$ exposed to waters samples V1

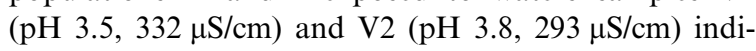
cated that (Fig. 2): (i) the most sensitive individuals (the first ones to die) were most probably only present in the reference population, since $15 \%$ of individuals died before any of the individuals from population I perished, and (ii) the most tolerant individuals (the latter ones to die) were most probably only present in the historically-stressed population, since, when the last individuals from population $\mathrm{R}$ died, 30 (V1) and 55\% (V2) of individuals from the population I were still alive. Since these individuals were neonates from recently field-collected egg-bearing females, which had been maintained in local water, differences in the extremes of lethal tolerance could be exclusively due to previous exposure of females from the population I (Klerks and Weis, 1987; Lam, 1999).

The highest lethal tolerance to intense AMD contamination by the stressed population was associated to a higher sub-lethal tolerance to moderate AMD contamination. After exposing individuals from the three populations to the water sample T1 (Fig. 3), the population I showed a higher fitness (neonates/female) than the reference ones ( $R$ and $R R$ ).

\subsection{Environmental versus genetic components of resistance}

Besides environmental-induced physiological alterations (including those due to stress-induced gene expres- sion), populations can evolve resistance by genetic adaptation (Klerks and Weis, 1987; Lam, 1999). This was the second goal of the present study: to assess whether the higher resistance shown by the historically-stressed population (I) was genetically-determined. The results obtained with acclimated individuals exposed to the water sample V3 (pH 6.0, $280 \mu \mathrm{S} / \mathrm{cm}$ ) supported this hypothesis (Fig. 4): since significant differences $(p=0.05)$ between the historically-stressed and reference populations, were still evident after controlling for maternal and external environmental influences (Klerks and Weis, 1987; Lam, 1999). These results indicate that probably a directional selection occurred in population I, since a directional shift in survival curve took place towards an increase in survival in heavy metal contaminated environments. Such genetically-determined resistance acquisition was found for other organisms and toxicants (Klerks and Weis, 1987; Reznick and Ghalambor, 2001; Klerks, 2002). Posthuma et al. (1993) observed that Collembola populations living in heavy metal contaminated sites had an increased excretion efficiency of metals than reference populations and were more tolerant to this type of contamination. They suggested that this was related with a strong directional selection pressure, induced by cadmium, which led to the selection of traits linked with tolerance. The results obtained in this study do not allow concluding for sure if the genetically-determined higher resistance of the population I was due to the disappearance of sensitive individuals or to the appearance of highly resistant ones. Results obtained with non-acclimated individuals exposed to the water samples V1 and V2 showed that the most sensitive individuals were most probably absent in population $\mathrm{I}$, since individuals in population $\mathrm{R}$ started to die much earlier. Furthermore, individuals from the population I died much latter than the ones from population R, suggesting that most tolerant individuals only occurred in the historically-stressed population. When exposed to the water sample V3 the most sensitive individuals were present in all the populations, since after $24 \mathrm{~h}$ of exposure mortality occurred in all populations. On the contrary, the most tolerant individuals were only present in the populations RR and I, corresponding to the $17 \%$ and $23 \%$ of survivors, respectively (in population $\mathrm{R}$ all individuals died). This difference between results obtained with non-acclimated (samples V1 and V2) and acclimated individuals (V3) might indicate that the higher resistance of non-acclimated individuals from population I was due to both environmental and genetical components, while after acclimation to controlled conditions (the environment influence disappeared) individuals from population I become less resistant, and, thus the most sensitive among these individuals died at the same time as the ones from the populations $\mathrm{R}$ and RR. Furthermore, the frequency of the most sensitive individuals was much lower in the historically- 
stressed population than in reference populations, since most of the individuals from I died much latter than most of those from the reference populations. No conclusion could be drawn about the presence of individuals with an extreme genetically-determined resistance in the historically-stressed population. In addition, it was reported in literature (Forbes and Depledge, 1996) that impacted populations exhibiting higher EC50 and lower slopes of survival curves indicates intermediate selection, since sensitive individuals are still present in the population. This is in agreement with the results obtained with acclimated organisms, thus involving genetic differences, which suggests the presence of sensitive individuals both in reference and impacted populations.

In conclusion, a strong genetically-determined increase in resistance in population I was demonstrated in the present study, and was probably due to genetic erosion: the loss of genetic variability through the disappearance of sensitive individuals present in the original founder population.

Although being beyond this study aims, results here obtained also suggested that resistance differences between the reference and the stressed populations increased with increasing toxicity, as indicated by individuals exposed to the contaminated samples V1 and V2 $(p<0.001)$ and to T1 $(p=0.016)$. Furthermore, a smaller difference was found in the assay with acclimated individuals exposed to the water sample V3 (null hypothesis rejected at $p=0.05$ ) than the difference found with non-acclimated individuals exposed to samples V1 and V2 $(p<0.001)$. Therefore, at lethal levels of toxicity, results here obtained suggest a convergence in resistance responses between the reference and the stressed populations from high to low levels of contamination: $\mathrm{V} 1$ and $\mathrm{V} 2$ to V3. Furthermore, a convergence is also present between lethal and sub-lethal levels of toxicity (V2 and V1 to T1, and V3 to T1). Although it is not common to find works where responses to different lethal levels of toxicity are compared, some authors compared responses at different toxicity levels and found a convergence in responses from high to low levels of contamination. Barata et al. (2000) compared toxicity in resistant and sensitive clones of D. magna exposed to lethal and sublethal levels of cadmium, and found that genetic variance in resistance to cadmium converge from lethal to sub-lethal responses and, also, from high to low levels of sub-lethal effects. Furthermore, Leppänen et al. (1998) compared survival and feeding activity (egestion rates) between natural populations of the midge Chironomus riparius Meigen originated from reference and heavy metal impacted sites, and found that larvae from contaminated sites exhibited a higher lethal resistance to contaminated sediments than larvae from reference sites, though differences were not found at sub-lethal levels of contamination.

\section{Acknowledgement}

This work was partially funded by Fundação para a Ciência e a Tecnologia (Portugal)_PRAXIS XXI (the PIN project, contract POCTI/CED/34891/99).

\section{References}

ASTM, 2002. Standard guide for conducting acute toxicity tests on test materials with fishes, microinvertebrates and amphibians. E 729-796. Annual Book of American Society of Testing and Materials Standards, vol. 11.05. Philadelphia, PA, USA.

Baird, D.J., Soares, A.M.V.M., Girling, A., Barber, M.C., Calow, P., 1989. The long term maintenance of Daphnia magna Straus for use in ecotoxicity tests: Problems and prospects. In: Lokke, H., Tyle, H., Bro-Rasmussen, F. (Eds.), Proceedings of the 1st European Conference on Ecotoxicology, 17-19 October 1986. Lyngby, Denmark, pp. 144-148.

Barata, C., Baird, D.J., Miñarro, A., Soares, A.M.V.M., 2000. Do genotype always converge from lethal to non-lethal toxicant exposure levels? Hypothesis tested using clones of Daphnia magna Straus. Environ. Toxicol. Chem. 19, 2314 2322.

Bodar, C.W.M., Van der Sluis, I., van Montfort, J.C.P., Voogt, P.A., Zandee, D.I., 1990. Cadmium resistance in Daphnia magna. Aquat. Toxicol. 16, 33-40.

Borgmann, U., Norwood, W.P., Clarke, C., 1993. Accumulation, regulation and toxicity of copper, zinc, lead and mercury in Hyalella azteca. Hydrobiologia 259, 79-89.

Brown, B.E., 1978. Lead detoxification by a copper-tolerant isopod. Nature 276, 388-390.

Bruins, M.R., Kapil, S., Oehme, F.W., 2000. Microbial resistance to metals in the environment. Ecotoxicol. Environ. Saf. 45, 198-207.

Castro, B.B., Guilhermino, L., Ribeiro, R., 2003. In situ bioassay chambers and procedures for assessment of sediment toxicity with Chironomus riparius. Environ. Pollut. $125,325-335$.

Castro, B.B., Sobral, O., Guilhermino, L., Ribeiro, R., 2004. An in situ bioassay integrating individual and biochemical responses using small fish species. Ecotoxicology 13, 667681.

Cope, W.G., Wiener, J.G., Atchison, G.J., 1994. Hepatic cadmium, metal-biding proteins and bioaccumulation in bluegills exposed to aqueous cadmium. Environ. Toxicol. Chem. 13, 553-562.

Depledge, M.H., Weeks, J.M., Bjerregaard, P., 1994. Heavy metals. In: Calow, P. (Ed.), Handbook of Ecotoxicology. Blackwell Scientific Publications, Oxford, UK, pp. 79105.

Devars, S., Hernández, R., Moreno-Sánchez, R., 1998. Enhanced heavy metal tolerance in two strains of photosynthetic Euglena gracilis by preexposure to mercury or cadmium. Arch. Environ. Contam. Toxicol. 34, 128-135.

Donker, M.H., Zonneveld, C., van Straalen, N.M., 1993. Early reproduction and increased reproductive allocation in metal-adapted populations of the terrestrial isopod Porcellio scaber. Oecologia 96, 316-323. 
Forbes, V., Depledge, M.H., 1996. Environmental stress and the distribution of traits within populations. In: Baird, D.J., Maltby, L., Greig-Smith, P.W., Douben, P.E.T. (Eds.), Ecotoxicology: Ecological Dimensions. Chapman \& Hall, London, UK, pp. 71-86.

Gerhardt, A., 1995. Effects of metals on stream invertebrates. PhD Thesis, Lund University, Lund, Sweden.

Gill, H.J., Nida, D.L., Dean, D.A., England, M.W., Jacobson, J.B., 1989. Resistance of Drosophila to cadmium: Biochemical factors in resistant and sensitive strains. Toxicology 56, 315-321.

Hamer, D.H., 1986. Metallothionein. Ann. Rev. Biochem. 55, 913-951.

Hickey, W.C., 1989. Sensitivity of four New Zealand cladoceran species and Daphnia magna to aquatic toxicants. New Zealand J. Mar. Freshwater Res. 23, 131-137.

Jak, R.G., Maas, J.L., Scholten, M.C.Th., 1996. Evaluation of laboratory derived toxic effect concentrations of a mixture of metals by testing freshwater plankton communities in enclosures. Wat. Res. 30, 1215-1227.

Kelly, M., 1988. Mining and the Freshwater Environment. Elsevier Science Publishers, Essex, UK.

Klerks, P.L., 2002. Adaptation, ecological impacts, and risk assessment: insights from research at Foundary Cove, Bayou Trepagnier, and Pass Fourchon. Human Ecol. Risk Assess. 8, 971-982.

Klerks, P.L., Weis, J.S., 1987. Genetic adaptation to heavy metals in aquatic organisms: A review. Environ. Pollut. 45, 173-205.

Krane, D.E., Sternberg, D.C., Burton, G.A., 1999. Randomly amplified polymorphic DNA profile-based measures of genetic diversity in caryfish correlated with environmental impacts. Environ. Toxicol. Chem. 18, 504-508.

Lam, P.K.S., 1996. Interpopulation differences in acute response of Brotia hainanensis (Gastropoda, Prosobranchia) to cadmium: Genetic or environmental variance? Environ. Pollut. 94, 1-7.

Lam, P.K.S., 1999. Methods for distinguishing genetic and environmental variance in stress tolerance. Ecol. Appl. 9, $449-455$

Leppänen, M.T., Postma, J.F., Groenendijk, D., Kukkonen, J.V.K., Buckert-de Jong, M.C., 1998. Feeding activity of midge larvae (Chironomus riparius Meigen) in metal polluted-river sediments. Ecotoxicol. Environ. Saf. 41, 251257.

Lopes, I., Gonçalves, F., Soares, A.M.V.M., Ribeiro, R., 1999a. Ecotoxicological tools in the remediation of acid mine drainage. Toxicol. Environ. Chem. 70, 441460.

Lopes, I., Gonçalves, F., Soares, A.M.V.M., Ribeiro, R., 1999b. Discriminating the ecotoxicity due to metals and to low $\mathrm{pH}$ in acid mine drainage. Environ. Ecotoxicol. Saf. 44, 207-214.

Lopes, I., Gonçalves, F., Soares, A.M.V.M., Ribeiro, R., 2000. Field validation of specific ecotoxicological tools for aquatic systems impacted with acid mine drainage. Int. J. Environ. Stud. 58, 3-20.

Lucan-Bouché, M.-L., Biagianti-Risbourg, S., Arsac, F., Vernet, G., 1999. An original decontamination process developed by the aquatic oligochaete Tubifex tubifex exposed to copper and lead. Aquat. Toxicol. 45, 9-17.
Macnair, M.R., 1997. The evolution of plants in metalcontaminated environments. In: Bijlsma, R., Loeschcke, V. (Eds.), Environmental Stress, Adaptation and Evolution. Biekhauser Verlag, Basel, Switzerland, pp. 3-24.

Maltby, L., Calow, P., Cosgrove, M., Pindar, L., 1987. Adaptation to acidification in aquatic invertebrates; speculation and preliminary observations. In: Witters, H., Vanderborght, O., (Eds.), Ecophysiology of Acid Stress in Aquatic Organisms. Annls. Soc. Roy. Zool. Belg. 117, Suppl. 1, pp. 105-115.

Maltby, L., Crane, M., 1994. Responses of Gammarus pulex (Amphipoda, Crustacea) to metalliferous effluents: Identification of toxic components and the importance of interpopulation variation. Environ. Pollut. 84, 45-52.

Mance, G., 1987. Pollution Threat of Heavy Metals in Aquatic Environments. Elsevier Publishers, London, UK.

Miliou, H., Zaboukas, N., Moraitou-Apostolopoulou, M., 1998. Biochemical composition, growth, and survival of the Guppy, Poecilia reticulata, during chronic sublethal exposure to cadmium. Arch. Environ. Contam. Toxicol. 35, $58-63$.

Monni, S., Salemaa, M., Millar, N., 2000. The tolerance of Empetrum nigrum to copper and nickel. Environ. Pollut. 109, 221-229.

Moreira-Santos, M., Soares, A.M.V.M., Ribeiro, R., 2004a. An in situ bioassay for freshwater environments with the microalga Pseudokirchneriella subcapitata. Ecotoxicol. Environ. Saf. 59, 164-173.

Moreira-Santos, M., Soares, A.M.V.M., Ribeiro, R., 2004b. A phytoplankton growth bioassay for routine in situ environmental assessments. Environ. Toxicol. Chem. 23, 15491560.

Munger, C., Hare, L., Craig, A., Charest, P.-M., 1999. Influence of exposure time on the distribution of cadmium within the cladoceran Ceriodaphnia dubia. Aquat. Toxicol. 44, 195-200.

Münzinger, A., 1990. Effects of nickel on Daphnia magna during chronic exposure and alterations in the toxicity to generations pre-exposed to nickel. Wat. Res. 24, 845-852.

Murdoch, M.H., Hebert, P.D.N., 1994. Mitochondrial DNA diversity of brown bullhead from contaminated and relatively pristine sites in the Great Lakes. Environ. Toxicol. Chem. 13, 1281-1289.

Pereira, A.M.M., Soares, A.M.V.M., Gonçalves, F., Ribeiro, R., 1999. Test chambers and test procedures for in situ toxicity testing with zooplankton. Environ. Toxicol. Chem. 18, 1956-1964.

Pereira, A.M.M., Soares, A.M.V.M., Gonçalves, F., Ribeiro, R., 2000. Water-column, sediment, and in situ chronic bioassays with cladocerans. Environ. Ecotoxicol. Saf. 47, 27-38.

Pereira, E.G., Moura, I., Costa, J.R., Mahony, J.D., Thomann, R.V., 1995. The S. Domingos Mine: A study of heavy metals contamination in the water column and sediments of the Chança river basin by discharge from an ancient cupriferous pyrite mine (Portugal). Mar. Freshwater Res. 46, 145-151.

Posthuma, L., van Straalen, N.M., 1993. Heavy metal adaptation in terrestrial invertebrates: A review of occurrence, genetics, physiology and ecological consequences. Comp. Biochem. Physiol. 106, 11-38. 
Posthuma, L., Hogervorst, R.F., Joosse, E.N.G., et al., 1993. Genetic variation and covariation for characteristics associated with cadmium tolerance in natural populations of the springtail Orschesella cincta (L.). Evolution 47, 619631.

Posthuma, L., Hogervorst, R.F., van Straalen, N., 1992. Adaptation to soil pollution by cadmium excretion in natural populations of Orchesella cincta (L.) (Collembola). Arch. Environ. Contam. Toxicol. 22, 146-156.

Pyke, D.A., Thompson, J.N., 1986. Statistical analysis of survival and removal rate experiments. Ecology 67, 240245.

Reinecke, S.A., Prinsloo, M.W., Reinecke, A.J., 1999. Resistance of Eisenia fetida (Oligochaeta) to cadmium after longterm exposure. Ecotoxicol. Environ. Saf. 42, 75-80.

Reznick, D.N., Ghalambor, C.K., 2001. The population ecology of contemporary adaptations: What studies reveal about the conditions that promote adaptive evolution. Genetica 112-113, 183-198.

Ribeiro, R., Martins, A.M.A., Correia, J.C.A., Lopes, I., Pereira, A.M.M., Canteiro, M.H.S.F., Gonçalves, F., Soares, A.M.V.M., 1995. Vertebrados da zona da Mina de S. Domingos (Baixo Alentejo). Ciênc. Biol. Ecol. Syst. 15, 33-47.

Ribeiro, R., Lopes, I., Pereira, A.M.M., Gonçalves, F., Soares, A.M.V.M., 2000. Survival time of Ceriodaphnia dubia in acid waters with metal contamination. Bull. Environ. Contam. Toxicol. 64, 130-136.

Roesijadi, G., 1992. Metallothioneins in metal regulation and toxicity in aquatic animals. Aquat. Toxicol. 22, 81-114.

Sakuma, M., 1998. Probit analysis of preference data. Appl. Entomol. Zool. 33, 339-347.
Sengupta, M., 1993. Environmental Impacts of Mining: Monitoring, Restoration and Control. Lewis Publishers, Boca Raton, FL, USA.

Shirley, M.D.F., Sibly, R.M., 1999. Genetic basis of a betweenenvironment trade-off involving resistance to cadmium in Drosophila melanogaster. Evolution 53, 826-836.

Stohs, S.J., Bagchi, D., 1995. Oxidative mechanisms in the toxicity of metal-ions. Free Rad. Biol. Med. 18, 321-336.

Stuhlbacher, A., Bradley, M.C., Naylor, C., Calow, P., 1993. Variation in the development of cadmium resistance in Daphnia magna Straus; effect of temperature, nutrition, age and genotype. Environ. Pollut. 80, 153-158.

Stuhlbacher, A., Maltby, L., 1992. Cadmium resistance in Gammarus pulex (L.). Arch. Environ. Contam. Toxicol. 22, 319-324.

USEPA, 1991. Methods for measuring the acute toxicity of effluents and receiving waters to freshwater and marine organisms. In: Weber, C.I. (Ed.). EPA/600/4-90/027. Environmental Protection Agency, Office of Research and Development, Cincinnaty, OH, USA.

Van Straaalen, N.M., Timmermans, M.J.T.N., 2002. Genetic variation in toxicant-stressed populations: An evaluation of the "genetic erosion" hypothesis. Human Ecol. Risk Assess. 8, 983-1002.

Villaescusa, I., Martí, S., Matas, C., Martínez, M., Ribó, J.M., 1997. Chromium(VI) toxicity to luminescent bacteria. Environ. Toxicol. Chem. 16, 871-874.

Wiederholm, T., Dave, G., 1989. Toxicity of metal polluted sediments to Daphnia magna and Tubifex tubifex. Hydrobiologia 176/177, 411-417.

Zar, J.H., 1996. Biostatistical Analysis. Prentice-Hall International, New Jersey, NJ, USA. 